Nig. J. Pure \& Appl. Sci. Vol. 33 (Issue 1, 2020)
eISSN 2756-4045
Life Sciences, Univ. of Ilorin, Nigeria
www.njpas.com.ng

doi: http://dx.doi.org/10.48198/NJPAS/20.A14

\title{
Susceptibility of Staphylococcus aureus, and Candida albicans isolated from an Outdoor Swimming Pool in Abraka, Delta State, Nigeria
}

\author{
Iloba, Kate Isioma $^{1^{*}}$, Adamu, Kabir Mohammed ${ }^{2}$ and Onojayefe, Ruth Ogheneneobolwe ${ }^{1}$
}

${ }^{1}$ Department of Animal and Environmental Biology, Faculty of Science, Delta State University, Abraka, Delta State, Nigeria.

${ }^{2}$ Department of Biological Sciences, Ibrahim Badamasi Babangida University, Lapai, Niger State, Nigeria.

\section{ABSTRACT}

The use of outdoor swimming-pools during recreational activities and to practice swimming is on the increase, as against the use of natural water bodies due to increase rate of drowning and the possibility, of contaminations of water-borne diseases. In this study, a well-patronised outdoor swimming pool, in a densely populated town, Abraka community, Delta State, Nigeria, was assessed for the presence of Staphylococcus aureus, and Candida albicans isolates. The susceptibility potentials of these isolates to some antibiotics were investigated with standard techniques. Water samples were taken from four locations and in three phases (Before use, during use and before discharge) in sterilised sample bottles. During the sampling period, water temperature and $\mathrm{pH}$ were also monitored. Standard techniques and procedures were adopted for the isolation and identification of the isolates. The two isolates (Staphylococcus aureus, and Candida albicans) were present in the sampled water specimen in high frequency. Higher frequencies of the isolates were recorded before changing the water. The $\mathrm{pH}$ and water temperature monitored were significantly $(\mathrm{p}<0.05)$ different in water samples obtained during water usage and before changing the water with the water before usage. The two isolates were susceptible to Pefloxacin, Rocephin and Ciprofloxacin antibiotics only. Therefore, the occurrence of these isolates in public swimming pool indicated the precarious pool state and a vehicle for the transmission of the isolates. Proper and rotational water hygiene should be practised to curb the presences of the isolates.

Keywords: Bacterium, Fungus, Lentic, Recreation, Public Health.

\section{Introduction}

Recreation is seen as a value to individual and society which is unrestricted to swimming. It could be an attitude of mind regarding leisure behaviour that has a direct influence on factors that creates personality (Torkildsen, 1999). Swimming can be performed either in natural or artificial waters (such as swimming pool). Swimming pools are water contained either in concrete tanks, large artificial basin, or sizeable paved holes (Alcock, 1979). According to Cairns and Dickson (2003), swimming pool waters should meet potable water standard. However, where it is compromised, the water thereof, poises danger to human health and the environment (Cairncross et al., 2000; WHO, 2001). Several studies have been conducted on sanitary and quality control of swimming pools

\section{Corresponding Author: Iloba, K. Isioma}

Department of Animal and Environmental Biology, Faculty of Science, Delta State University, Abraka, Delta State, Nigeria. Phone: +234- 8036761306: Email: kisyiloba@gmail.com 
using microbiological evaluation (Ayandele et al., 2015).

Studies have shown that Staphylococcus aureus(bacteria) and Fungi Candida albicans

Page | 3660 (fungi) isolates are one of most frequently isolated pathogenic organisms in polluted human waters (Adamu et al., 2017; Adamu et al., 2018) as they are indicators of unhealthy ecosystem (Jacob et al., 2016). Studies also revealed that Staphylococcus aureus is responsible for a variety of infections such as osteomyelitis, pneumonia, conjunctivitis, urinary tract infections in human (Hussain et al., 2017, Wolff et al., 2013). Candida albicans exist as the first-rate causes of invasive fungal infections (Abu-Elteen and Hamad, 2012, Pfaller and Diekema, 2004). C. albicans commonly found in the oral cavity, gastrointestinal tracts and genital areas as harmless commensals (Abu-Elteen and Hamad, 2012). However, it is an opportunist pathogen capable of causing wide ranges of localised or superficial and systemic infections Pfaller and Diekema, 2004). It is the principal candidate in oral candidiasis (Davies et al., 2006) and vulvovaginal candidiasis (Davies et al., 2006).

Therefore, evaluating the potential of Staphylococcus aureus, and Candida albicans in an outdoor swimming pool, patronised heavily by the public especially students in Abraka, Delta State, Nigeria will provide more information on the health status of the pool and its suitability for the purpose. The study also tends to ascertain the susceptibility of these isolates to some commonly available antibiotics.

\section{Materials and Methods Study Area}

The study was conducted in an outdoor swimming pool, located on Longitude and Latitude of $5.7894^{\circ} \mathrm{N}$ and $6.1023{ }^{\circ} \mathrm{E}$ (Fig. 1), Abraka, Delta State, Nigeria. The pool is floored with white ceramic tiles of different shapes and sizes. It is $9 \mathrm{ft}$ deep and $23 \mathrm{~m} \times 40 \mathrm{~m}$ wide.

\section{Sample Collection}

The water sample was collected in duplicate from four sampling sites on three occasions (Before public usage, while using and before changing the water). The samples were transferred into a well labelled, sterilised wide-mouthed bottle for Staphylococcus aureus, and Candida albicans isolation and identification. Sampling was done following the method of Ademorati (1996). The sample-collection bottles were washed out thrice with the sample water before collection of samples. The collection was done by dropping the sample bottles to about $20 \mathrm{~cm}$ below the water surface, tilting the mouth of the bottle. The samples were preserved in an ice case and immediately moved to the laboratory for investigation. The water $\mathrm{pH}$ and temperature were checked using $\mathrm{pH}$ meter (Hanna) and mercury- in - glass thermometer (APHA, 2005), respectively before sampling.

\section{Experimental Procedures}

Following sterile procedures, ten-fold successive dilution of the water sample was made; from which $0.1 \mathrm{ml}$ was plated into a sterile Petri dish. Nutrient Agar (NA) (Titan Biotech) preparation was based on the manufacturer's specification. The medium was poured onto a sterile petri dish containing $0.1 \mathrm{ml}$ of the sample employing pour plate techniques. After that, the plate was incubated at $37^{\circ} \mathrm{C}$ for 24 hours to obtain mixed culture. Isolated colonies were recorded and then purified to acquire pure culture achieved repetitively through subculturing on new media for primary isolation in the manner represented/ delineated/described by Chikezie (2015). Pure stock cultures obtained were inoculated on NA slant and preserved in the refrigerator at $4^{\circ} \mathrm{C}$ before sensitivity test. The identification was based on its biochemical characteristics (gram stain, production of catalase and coagulase, urease, citrate, oxidase, indole, methyl red, glucose, lactose and sucrose) that were performed as described in Cheesebrough (2000) and Adeoye (2007). 
Germ Tube Formation was used to identify the fungus isolate grown on Potato Dextrose Agar as described in Adamu et al. (2018). After that, the use of Lactophenol cotton blue-green before observation with x100 objective lenses was

Page | 3661 employed to confirm the isolates. Antibiotic susceptibility was carried out on the isolates using disc diffusion method with inoculated solidified nutrient agar and incubated at $37^{\circ} \mathrm{C}$ for 24 hours and was observed for susceptibility and resistance profile (Cheesbrough, 2000).

\section{Statistical Analysis}

Past statistical software 2000 was used to employ the One-way ANOVA to explore significant differences in the $\mathrm{pH}$ and temperature of the pool at the different designated period of use.

\section{Results}

The mean and standard error values of the determined $\mathrm{pH}$ and temperature of the swimming water are presented in Table 1. It was observed that as the usage of the water continues before the change, the $\mathrm{pH}$ of the water was acidic with a higher temperature value of $31.34 \pm 1.04^{\circ} \mathrm{C}$. Table 2 reveals the phenotypic methods used for the identification of the isolates. Table 3 presents the total bacterial and fungal counts of three sampling phases. Table 3 also compares the isolates abundance with the WHO acceptable limit. The susceptibility test performed with fourteen (14) commonly available antibiotics revealed only three (3) (pefloxacin, rocephalin and ciprofloxacin) were the only antibiotics that the isolates where susceptive to (Table 4).

Table 1: Mean and standard error of $\mathrm{pH}$ and water temperature monitored in an outdoor swimming pool in Abraka, Delta State.

\begin{tabular}{lll}
\hline Sampling Period & $\mathrm{pH}$ & Temperature $\left({ }^{\circ} \mathrm{C}\right)$ \\
\hline Before Use & $6.89 \pm 0.38$ & $29.25 \pm 0.45$ \\
While in Use & $5.04 \pm 1.24 *$ & $30.64 \pm 1.44^{*}$ \\
Before Change & $4.12 \pm 0.34 *$ & $31.34 \pm 1.04 *$ \\
\hline${ }^{*} \mathrm{P}<0.05$ & &
\end{tabular}

Table 2: Phenotypic identification methods adopted for the identification of the isolates.

\begin{tabular}{lll}
\hline Parameters & $\begin{array}{l}\text { Stapylococus } \\
\text { aureus }\end{array}$ & $\begin{array}{l}\text { Candida } \\
\text { albicans }\end{array}$ \\
\hline Catalase & + & NA \\
Coagulate & + & NA \\
Methyl red & - & NA \\
Gram reaction & + & NA \\
Gem tube & NA & + \\
Spore staining & NA & + \\
\hline \multicolumn{1}{c}{+ positive, } & $-:$ negative, NA: not applicable
\end{tabular}

Table 3: Total Bacterial and Fungal counts in the three phases sampled in an outdoor swimming pool in Abraka, Delta State.

\begin{tabular}{lllll}
\hline Isolates & $\begin{array}{l}\text { Before } \\
\text { Use } \\
\text { CFU/ml }\end{array}$ & $\begin{array}{l}\text { During } \\
\text { Use } \\
\text { CFU/ml }\end{array}$ & $\begin{array}{l}\text { Before } \\
\text { Discharge } \\
\text { CFU/ml }\end{array}$ & $\begin{array}{l}\text { WHO Acceptable } \\
\text { Limit }\end{array}$ \\
\hline $\begin{array}{l}\text { S. } \\
\text { aureus }\end{array}$ & 7 & 2 & 18 & $\leq 1 \mathrm{CFU} / 100 \mathrm{ml}$ \\
$\begin{array}{l}\text { C. } \\
\text { albicans }\end{array}$ & 3 & 5 & 6 & $\leq 1 \mathrm{CFU} / 100 \mathrm{ml}$ \\
\hline
\end{tabular}

Table 4: Antibiotics susceptibility/Resistance profile of the bacterium and fungus to some selected antibiotics tablets

\begin{tabular}{|c|c|c|c|}
\hline \multirow[t]{2}{*}{ Antibiotics } & \multirow[t]{2}{*}{ Concentration } & \multicolumn{2}{|c|}{ Isolate } \\
\hline & & $\begin{array}{l}S . \\
\text { aureus }\end{array}$ & $\begin{array}{l}C . \\
\text { albicans }\end{array}$ \\
\hline Pefloxacin & $10 \mu \mathrm{g} / \mathrm{ml}$ & + & + \\
\hline Gentamycin & $10 \mu \mathrm{g} / \mathrm{ml}$ & + & - \\
\hline Ampliclox & $30 \mu \mathrm{g} / \mathrm{ml}$ & - & - \\
\hline Zinnacef & $20 \mu \mathrm{g} / \mathrm{ml}$ & - & - \\
\hline Amoxicillin & $30 \mu \mathrm{g} / \mathrm{ml}$ & - & - \\
\hline Rocephin & $25 \mu \mathrm{g} / \mathrm{ml}$ & + & + \\
\hline Ciprofloxacin & $10 \mu \mathrm{g} / \mathrm{ml}$ & + & + \\
\hline Streptomycin & $30 \mu \mathrm{g} / \mathrm{ml}$ & + & - \\
\hline Erythromycin & $10 \mu \mathrm{g} / \mathrm{ml}$ & + & - \\
\hline Chloranphenicol & $30 \mu \mathrm{g} / \mathrm{ml}$ & + & - \\
\hline Augumentin & $30 \mu \mathrm{g} / \mathrm{ml}$ & + & - \\
\hline Tarivid & $10 \mu \mathrm{g} / \mathrm{ml}$ & - & - \\
\hline Septrin & $10 \mu \mathrm{g} / \mathrm{ml}$ & - & - \\
\hline Sparfloxacin & $30 \mu \mathrm{g} / \mathrm{ml}$ & + & - \\
\hline
\end{tabular}




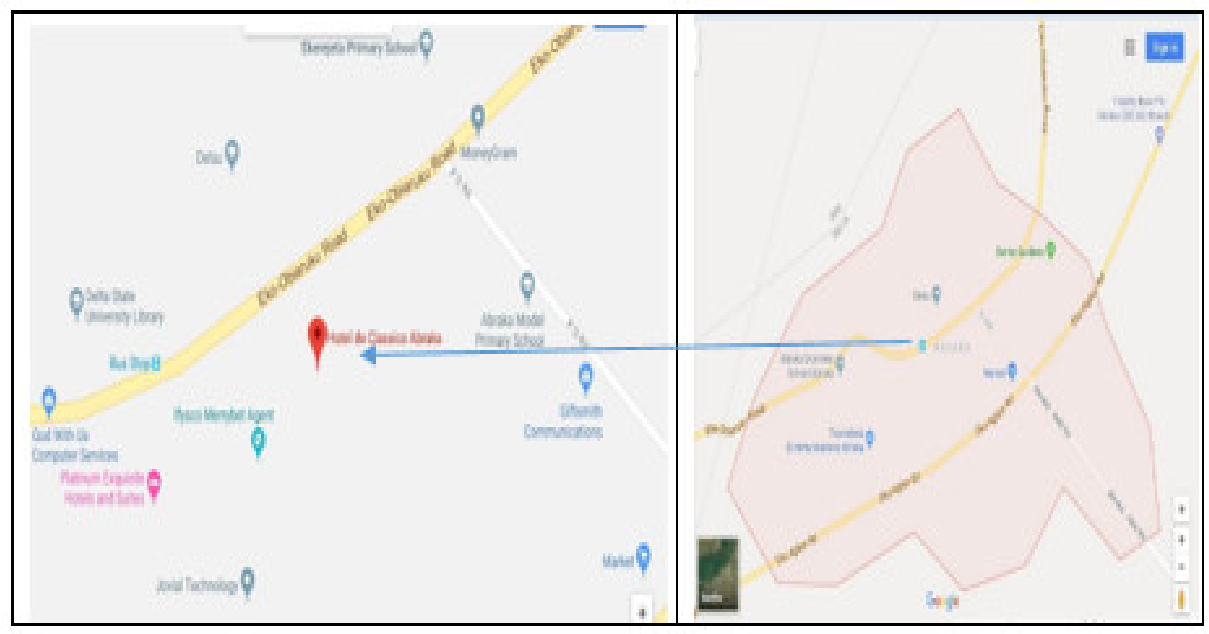

Fig 1: Map of Study Site using google earth location map (2019)

\section{Discussion}

The isolation of these pathogens in swimming pools has been reported by other researchers (Olorunjuwon, 2012; Abu-Elteen and Hamad, 2012). The affinity for one another could be due to the adherence of Staphylococcus aureus to the filamentous fungus; Candida albicans (Peters et al., 2012) and thus both found drifting in the swimming pool. The co-isolation of Candida albicans and Staphylococcus aureus has been reported by several researchers and synergistically causing morbidity and deaths in humans (Todd et al., 2019). The concomitant existence of these pathogens could be symbiotically related to their indigenousness in man. The acidic water with its corresponding high-temperature value may be attributed to the polluted state of the water as a result of the presences of Candida albicans and Staphylococcus aureus amongst other pathogens that may be present in the water. The elevated frequency (count) of these isolates in the swimming pool after usage is a strong indication that the pool was impacted by the swimmers, which are latent carriers of these pathogens. Besides the mucosal contaminations (Todd et al., 2019), the faecal-en route could be another possible source of these pathogens when pool users do not observe utmost sanitary measures (Ekopai et al., 2017). As a spherical bacterium, $S$. aureus often found embedded in man en route the nose and skin of people have survived to a great extent outside the human. More so, notably infected persons with skin infections as well as life-threatening diseases caused by these pathogens are not screened out from using the pool (Ajadi and Thonda, 2017). Similarly, C. albicans, a diploid filamentous fungus; is opportunistic in nature indicted in causing oral and genital infection diseases in humans (Ryan and Ray, 2004) invading men using hyphae (Peters et al., 2012; Onifade et al., 2019). The reduced number of isolates after the change of water has exonerated biofilms formations along the pipes as another probable means of contaminating the pool. The concomitant occurrence of both organisms is therefore of great public health message as they may be responsible for the persistence, resistance and advancement of so many diseases (Shirtliff and Leid, 2009; Melton and Anderson, 2018; Jamel et al., 2018). Thus, their presence in a public swimming pool may provide an accessible vehicle for its transmission. The aggregation of $60-100$ bathers 
at a time in the given size of the studied pool was worrisome and considered a public nuisance. This clustering, which is an express spread of diseases must be stopped. The antibiotic susceptibility test revealed that the isolates were resistant to most of Page | 3663 the antibiotics and antifungal agents used for treating infections. Thus, it could be challenging to treat an infection acquired from the swimming pools arising from such organisms (Son et al., 1997). Researchers have reported on the susceptibility of the tested antibiotics on the pathogens (Onwubiko and Sadip, 2011; Al-Zoubi et al., 2015). Swimming pool users must endeavour not to gulp in the water while swimming and be quick to wash after swimming with disinfectant.

The study thereof revealed that the swimming pool did not meet the standards of WHO and EPA for recreational water quality. Despite the acclaimed disinfection of the pool water weekly with $\quad 100 \mathrm{~g} \quad$ chlorine $/ 150 \mathrm{Ash} / 1 \mathrm{~kg} \quad$ Alum (Questionnaire). The intensity of the isolates during use of pool suggests improper or no treatments as well as the use of substandard disinfectants (Ekopai et al., 2017). The presence of Staphylococcus aureus and Candida albicans discovered in the swimming pool is not desirable for recreational water.

\section{Acknowledgement}

The authors are thankful to the Director; Head of the Delta State University Center Laboratory, for allowing us to use the Laboratory facilities. We are also thankful to Mr Obaro Oyubu, of the Department of Science Laboratory Technology for analysing the water samples.

\section{Conflict of Interest}

There is no known contention.

\section{References}

Abu-Elteen, K.H. and Hamad, M.A. (2012). Changing Epidemiology of Classical an
Emerging Human Fungal Infections: A Review. Jordan Journal of Biological Sciences. 5(4): 215-230.

Adamu, K. M., Isah, I.Z., Iloba, I.K., Babadoko, A.M., Ikomi, R.B., Shuaibu, R., Olofinsan, K.A. and Ibrahim, A.A. (2018). Prevalence of Bacterial Isolates in Water and Some Biota of Lapai-Agaie Dam, Nigeria. Science World Journal. 13(4): 75-80.

Adamu, K.M., Aliyu-Paiko, M., Ikomi, R.B., Suleiman, S.A., Ahmed, I.B., Mamman. R. and Mohammed, S.S.D. (2017). Evaluating the Associate Microbial Organisms, Fish Feed Utilization Potential and Feedstock in Biogas Production of Water-Hyacinth; FUTA. Journal of Research in Sciences. 13(1): 25-38.

Ademorati, M.A. (1996). Standard Methods for water and effluent analysis, 1st ed. Foludex Press Ltd, Ibadan. Pp 80-83.

Adeoye, A. (2017). Medical Laboratory Practice, 1st Edition, FEMCO Publishers limited, Lagos, Nigeria, 153pp.

Ajadi, F.A. and Thonda, O.A. (2017). Microbial assessment of swimming pools from selected hotels in Osogbo metropolis, Osun State, Nigeria. Journal of Advances in Microbiology. 7(3): 1-10.

Alcock, S.R. (1979). Acute otitis extema in divers working in the North Sea. A microbiological survey of seven saturation divers. J. Hyg. 18: 359-409.

Al-Zoubi, M.S., Al-Tayyar, I.I., Hussein, E., AlJabali, A. and Khudairat, S. (2015). Antimicrobial susceptibility pattern of Staphylococcus aureus isolated from clinical specimen in Northern area of Jordan. Iranian Journal of Microbiology. 7(5): 265-272

APHA. (2005). Standard methods for the examination of water and wastewater (20th 
edn.) Washington: American Public Health Association, 1220pp.

Ayandele, A.A., Adebayo, E.A. and Oladipo, E.K. (2015). Assessment of Microbiological Quality of Outdoor Swimming Pools in Ilorin, Kwara State. Journal of Environmental Science, Toxicology and Food Technology. 2(8): 25- 30.

Cairncross, S.C., Curtis, D.G., Feahem, R.L. and Brandley, G.H. (2000). Evaluation of village water supply planning. Chichester: John Wiley and Sons, 229-55.

Cairns, J.J. and Dickson, K.L. (2003). Biological methods for the assessment of water quality. American water works Association, Bulletin.13-5.

Cheesbrough, M. (2000). Medical Laboratory Manual for Tropical Countries. Butter worth and Co. Ltd., UK, p:21-32.

Chikezie, I.O. (2015). Microbiological laboratory Manual. Micro trend Digital Press, Nigeria Ltd., pp21-29.

Davies, A.N., Brailsford, S.R. and Beighton, D. (2006). Oral candidiasis in patients with advanced cancer. Oral Oncol. 42: 698-702.

Ekopai, J. M., Musisi, N.L., Onyuth, H., Benigna, G.N. and Sente, C. (2017). Determination of Bacterial Quality of Water in Randomly Selected Swimming Pools in Kampala City, Uganda. New Journal of Science.1: 1-7. https://doi.org/10.1155/2017/1652598.

Hussain, M.Y., Ali-Nizam, A.A. and Abou-Isba, S.M. (2017). Antibacterial activities (Bacitracin A and Polymyxin B) of Lyophilised extract from indigenous Bacillus subtilis against Staphylococcus aureus. Jordan Journal of Biological Sciences. 10(3): 205-212.
Jacob, J.H., Irshaid, F.I. and Alhalib, M.A. (2016). Estimation and Identification of Airborne Bacteria and Fungi in the Outdoor Atmosphere of Al-Mafraq Area. Jordan Journal of Biological Sciences. 9(1): 3-10.

Jamal, M., Ahmad, W., Leeb, S., Jalil, F., Imran, M., Nawaz, M.A., Hussain, T., Ali M., Rafiq, M. and Kamil, M.A. (2018). Bacterial biofilm and assocated infections. Journal of the Chinese Medical Association. 81: 7-11.

Melton, C.N. and Anderson, G.G. (2018). Biofilms and Disease: A persistent threat. https://doi.org/10.1016/B978-0-12-8012383.66119-6.

Olorunjuwon, B. (2012). Microbial qualities of swimming pools in Lagos, Nigeria. International Journal of Applied Science and Technology. 2(8): 89 - 94.

Onifade, O.E., Olowe, B. M. and Obasanmi, J. (2019). Assessment of the Physicochemical and Bacteriological Quality of Public Swimming Pool in Selected Hotels in AdoEkiti, Nigeria. South Asian Journal of Research in Microbiology. 4(3): 1-9

Onwubiko, N.E. and Sadiq, N.M. (2011). Antibiotic sensitivity pattern of Staphylococcus aureus from clinical isolates in a tertiary health institution in Kano, Northwestern Nigeria. Pan African Medical Journal. 8: 4-11

Peters, B.M., Ovchinnikova, E.S., Krom, B.P., Schlecht, L. M., Zhou, H., Hoyer, L.L., Busscher, H.J., Van der Mei, H. C., JabraRizk, M. and Shirtliff, M. E. (2012). Staphylococcus aureus adherence to Candida albicans hyphae is mediated by the hyphal adhesin Als3p. Microbiology. 158: 2975-2986

Pfaller, M.A. and Diekema, D.J. (2007). Epidemiology of invasive candidiasis: a 
persistent public health problem. Clin Microbiolo. Rev. 20: 133-163.

Pfaller, M.A. and Diekema, D.J. (2004). Rare and emerging opportunistic fungal pathogens:

Page | 3665 concern for resistance beyond Candida albicans and Aspergillus fumigatus. J. Clin Microbiol. 42: 4419-4431.

Ryan, K.L. and Ray, C.G. (2004). In Sherris Medical Microbiology. An introduction to infectious disease (4th edition) Mc Graw Hill companies, inc, USA.

Shirtliff, M.E and Leid, J.G. (2009). Biofilms and Device - Related infections. Springer, New York, NY.

Son, R., Rusul, G., Sahilah., A.M., Zainuri, A., Raha, A.R and Salmah, I. (1997). Antibiotics resistance and plasmid profile of Aeromona ashydrophila isolates from cultured fish, Tilapia. Letters in Applied Microbiology. 24: 1-6.

Todd, O.A., Fidel, P.L., Harro, J.M., Hilliard, J.J., Tkaczyk. C., Sellman, B.R., Noverr, M.C., Peters, B.M. (2019). Candida albicans augmentsStaphylococcus aureus virulence by engaging the staphylococcal agr quorum sensing system. mBio 10:e00910-19. https://doi.org/10

$.1128 / \mathrm{mBio} .00910-19$.

Torkildsen, G. (1999). Leisure and Recreation Management. London, New York: Routledge.

WHO (2001). The health of swimmers depends on water quality, the physical, chemical and microbial content of the water. 32pp.

Wolff, K.., Johnson, R.A. and Saaveedra, A.P. (2013). Fitzpatrick's Color Atlas and Synopsis of Clinical Dermatology. Seventh ed. McGraw-Hill, USA. 